\title{
Jørgen Elklit
}

\section{Er der virkelig ingen argumenter for at ændre det kommunale valgsystem? ${ }^{1}$}

\begin{abstract}
Indenrigs- og sundhedsminister Lars Løkke Rasmussen udtalte i november 2003 i et svar i Folketinget, at der efter hans opfattelse ikke var argumenter for ved kommunalvalg m.m. at erstatte brugen af d'Hondts metode med største brøks metode, når mandaterne skal fordeles. Det vises imidlertid i artiklen, at der faktisk er en række argumenter for en sådan ændring, ikke mindst i den nuværende situation, hvor partisystemerne i kommuner og regioner må forventes at komme til at ligne det nationale partisystem mere og mere. Denne udvikling vil utvivlsomt blive fremmet af strukturændringerne på det kommunale område. De resultater, der præsenteres her, svarer i $\emptyset v r i g t$ til, hvad den nyeste forskning i andre lande viser.
\end{abstract}

I november 2003 spurgte Uno Larsson fra Dansk Folkeparti i Folketinget indenrigs- og sundhedsminister Lars Løkke Rasmussen, om der efter ministerens opfattelse var argumenter, der talte for at overveje at erstatte det d'Hondtske valgsystem, der bruges ved de kommunale valg, med største brøks metode, der anvendes ved folketingsvalgene (S 498).

Efter lidt historik og en kort beskrivelse af de to mandatfordelingssystemer kom ministeren i sit svar med nogle af argumenterne for og imod de to systemer, idet han sondrede mellem argumenter, der relaterer sig til matematisk retfærdighed, og argumenter, der relaterer sig til den politiske hensigtsmæssighed. I den første kategori nævnte han, at d'Hondts metode begunstiger de store partier - hvilket er velkendt - men også, at største brøks metode kan have en tendens til at begunstige de små partier, hvilket er et mere åbent spørgsmål, jf. nedenfor. Det blev også fremhævet, at d'Hondts metode aldrig kan føre til, at et stort parti snupper et helt mandat fra et andet parti, som dette forholdsmæssigt "har ret til"; det blev imidlertid ikke nævnt, at d'Hondts metode også kan føre til, at et stort parti får mere end et helt mandat mere, end det "har ret til", jf. igen nedenfor. Ministeren omtalte også valg- og listeforbunds modererende virkninger, hvilket også tages op nedenfor.

De politiske hensigtsmæssighedsargumenter vedrørte primært de to metoders betydning for partisammenhold og partisplittelse. Ministeren fremhævede også, at d'Hondts metode garanterer, at et parti med mere end halvdelen af stemmerne også får mindst halvdelen af mandaterne. Ministerens konklusion var derfor, at der ingen argumenter er for at ændre på den gældende tingenes tilstand.

Det spørgsmål, som her tages op i forlængelse af Larssons spørgsmål og ministerens svar, er, om der - på trods af ministerens svar i Folketinget - alligevel skulle være argumenter, der kunne tale for at erstatte den siden 1909 benyttede d'Hondtske metode ved kommunalvalg (samt amtsrådsvalg, menighedsrådsvalg og Europaparlamentsvalg) med en anden mandatfordelingsmetode. Som regel har man her største brøks metode i tankerne, men analyserne nedenfor viser faktisk, at Sainte-Laguës metode er et attraktivt alternativ til de to andre metoder. 
Kemen i diskussionen er, om det ene eller det andet mandatfordelingssystem (valgsystem/valgmåde) er "bedst". Det forudsætter imidlertid, at man er enige om, hvad det skal være bedst til, og hvad bedømmelseskriterieme og argumenteme derfor skal være.

Tidspunktet for en sådan diskussion er ikke dårligt. Fremtidens kommunale struktur er et centralt emne på den aktuelle politiske dagsorden, og der er derfor god anledning til at diskutere, dels hvordan de nye regionsråd skal vælges, dels om der er grund til at ændre den måde, kommunalbestyrelseme vælges på, når nogle af de mindste kommunalbestyrelser (især dem med 9, 11 eller 13 medlemmer) forsvinder i takt med etableringen af støre primærkommuner. Hertil kommer, at partimønstret $i$ kommuneme vil komme til at minde mere om det nationale partisystem end hidtil. Det må også forventes, at de kommende ændringer vil være et hårdere slag mod lokallisterne end Kommunalreformen i 1970.

Mandatfordelingsmetoders og valgsystemers samspil med partisystememe kan analyseres på flere måder. Spørgsmålet om, hvad en rimelig mandatfordeling er, vil i vore dage for mange hænge sammen med, om vælgemes stemmer tæller lige meget ved resultatopgørelsen, dvs. gives samme vægt, og om de partier og lister, man har stemt på, behandles så ensartet som muligt, dvs. uden nogen form for fordele eller forfordeling til store eller små partier og lister. Én oplagt målestok for, hvad der er rimeligt og retfærdigt, er den strengt matematiske retfærdighed - den højest mulige grad af forholdsmæssighed - også i behandlingen af de deltagende partier og lister, altså en tilgang, som ser sagen fra partiernes side. Vælgeme er dog også part i sagen; derfor er det også nødvendigt at se på, om vælgeme bliver repræsenteret i samme forhold, dvs. om mandatandelen pr. vælger er nogenlunde ens fra parti til parti. De to synsvinkler bygger grundlæggende på samme tankegang, men da de i litteraturen ofte studeres separat, vil det også ske her.

Matematisk retfærdighed er dog ikke det eneste kriterium, der kan inddrages i vurderingen af valgsystemer. Ministeren pegede i sit svar til Uno Larsson på hensynet til partisystemets udvikling, og også andre kriterier kunne inddrages (jf. Reynolds og Reilly, 1997: 9-14). Her vil fokus dog primært være på forholdet mellem stemmer og mandater, dvs. på den matematiske retfærdighed, mens andre hensyn kun tages op mere sporadisk.

Artiklen bygger primært på resultateme af kommunalvalget i november 2001. Det første hovedafsnit ser på billedet fra partiemes side, med fokus på proportionalitet og betydningen af valgforbund for de store partiers repræsentation. Det andet hovedafsnit ser så på billedet fra vælgemes side, og over- og underrepræsentationsproblematikken illustreres og diskuteres for forskellige typer af partier og kommuner og for alle landets kommuner under ét. Det vises også, at Sainte-Laguës metode (i sin rene form) ville kunne sikre såvel en højere proportionalitet i partiernes repræsentationsmønster som en mere ligelig repræsentation af vælgeme end største brøks metode. Til sidst konkluderes på det spørgsmål, som er artiklens titel.

\section{Billedet set fra partiernes side}

Det er velkendt, at forskellige mandatfordelingssystemer ikke virker på samme måde på partiemes mulighed for at opnå fuld forholdsmæssig repræsentation. Af 
hensyn til fremstillingens overskuelighed og relevans for den aktuelle situation ses primært på det d’Hondtske system og største brøks metode. Sainte-Laguës system vil dog også blive inddraget.

D'Hondts og Sainte-Laguës mandatfordelingssystemer er såkaldte divisorsystemer. Herved forstås, at partiernes stemmetal successivt divideres med elementerne i en divisorrakke, der i d'Hondts system er 1, 2, 3, .., n, .., i SainteLaguës system derimod kun de ulige tal, altså $1,3,5, \ldots,(2 n-1), \ldots$ (Elklit, 1997a, 2004). Mandaterne fordeles så i rækkefølge efter størrelsen af de ved divisionerne fremkomne kvotienter. Sainte-Laguës fordelingsmåde bruges ikke mange steder (især ikke i sin rene form), men den benyttes faktisk ved folketingsvalg til at fordele tillægsmandaterne på partier og landsdele (Elklit, 2004: 2 lff.).

Største brøks metode er en såkaldt kvotametode, hvor mandatfordelingen sker på grundlag af stemmetallets division med en kvota, her den såkaldte Hare-kvota (stemmetallet divideret med det samlede mandattal, eventuelt forhøjet til næste heltal). Partiernes stemmetal divideres med kvotaen, og hvert parti får i første omgang lige så mange mandater som antallet af gange, kvotaen går op i deres stemmetal. Alle mandaterne bliver sjældent fordelt i første omgang; resten fordeles så i anden omgang i rækkefølge efter størrelsen af partiernes restbrøker (deraf navnet).

Diskussioner af de tre metoders fordele og ulemper er der nok af. En af de ældste er dansk (Elberling/Nybølle, 1922). Senere variationer over de samme temaer ses hos Lijphart (1986, 1994), Gallagher (1991, 1992), Schuster et al. (2003), Pukelsheim (2000), Benoit (2000) og Pennisi (1998). Denne artikel bygger som nævnt på resultaterne af kommunalvalget i 2001. Konstruerede eksempler, som kan være nyttige i nogle sammenhænge (således Pennisi, 1998), kunne også have været brugt, ikke mindst til at illustrere mulige paradokser eller mærkværdigheder af anden art (se for eksempel Elberling/Nybølle, 1922: 340-341). Konstruerede eksempler fanger imidlertid sjældent virkelighedens praktiske realiteter, som de nu engang ses i de danske kommuner, og som er en væsentlig del af baggrunden for, at systemerne virker, som de gør, her og nu (jf. Elklit, 1997b).

Det vil nok være hensigtsmæssigt med en illustration af de tre valgsystemers virkemåde. I den forbindelse er det imidlertid et problem, at det er blevet meget udbredt, at de partier og lister, der opstiller ved et kommunalvalg, indgår valgforbund. Som regel indgås valgforbund mellem partier, der på en eller flere dimensioner ligger i nærheden af hinanden, men man ser dog hyppigere og hyppigere også valgforbund mellem partier, der ligger længere fra hinanden (Lynge, 2002). Forekomsten af valgforbund komplicerer beregningerne og konklusionerne; for at undgå sådanne komplikationer ses derfor først på de kommuner, hvor der i 2001 hverken forekom valg- eller listeforbund. Af den slags kommuner er der imidlertid kun ni. En af disse er Sindal i Nordjylland, hvor der i 2001 var 17 mandater til fordeling mellem de fire opstillede partier og Borgerlisten. De relevante oplysninger til vurdering af såvel det faktiske udfald i 2001 som konsekvenserne af de to andre fordelingsmetoder ses i tabel 1 .

Tabel 1 viser først listernes stemmetal og procentandel af stemmerne. Denne stemmefordeling førte ved brug af d'Hondts metode til, at Venstre fik ti af de 17 


\begin{tabular}{|c|c|c|c|c|c|c|c|}
\hline & 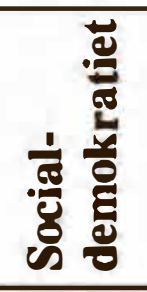 & 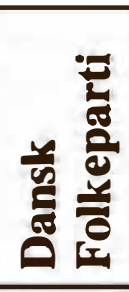 & 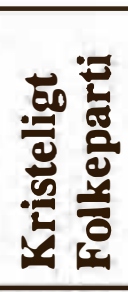 & 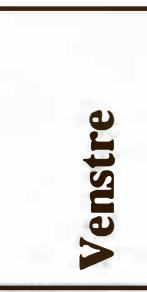 & 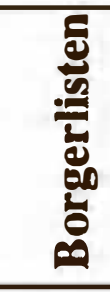 & Е & 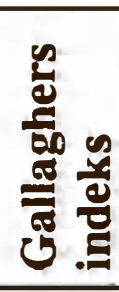 \\
\hline Stemmetal & 1.914 & 282 & 204 & 3.109 & 366 & 5.875 & \\
\hline Pct. & 32,6 & 4,8 & 3,5 & 52,9 & 6,2 & 100,0 & \\
\hline $\begin{array}{l}\text { Mandattal ved d'Hondts metode } \\
\text { (dvs. nuværende fordeling) }\end{array}$ & 6 & - & - & 10 & 1 & 17 & 6,2 \\
\hline Pct. & 35,3 & - & - & 58,8 & 5,9 & 100,0 & \\
\hline $\begin{array}{l}\text { Mandatfordeling ved største brøks } \\
\text { metode }\end{array}$ & 5 & 1 & 1 & 9 & 1 & 17 & 2,9 \\
\hline Pct. & 29,4 & 5,9 & 5,9 & 52,9 & 5,9 & 100,0 & \\
\hline $\begin{array}{l}\text { Mandatfordeling ved Sainte-Laguës } \\
\text { metode }\end{array}$ & 5 & 1 & 1 & 9 & 1 & 17 & 2,9 \\
\hline Pct. & 29,4 & 5,9 & 5,9 & 52,9 & 5,9 & 100,0 & \\
\hline
\end{tabular}

mandater, Socialdemokratiet seks og Borgerlisten ét. De to store partier fik procentuelt en større andel af mandaterne end af stemmerne, Venstre således næsten 59 pct. af mandaterne for knap 53 pct. af stemmerne.

Tabellens næste rækker viser, hvad brugen af største brøks metode og SainteLaguës metode ville have betydet. Socialdemokratiet og Venstre ville begge have fået et mandat mindre, mens Dansk Folkeparti og Kristeligt Folkeparti begge ville have fået et mandat, hvor de i 2001 slet ikke blev repræsenteret. Eksemplet illustrerer således den velkendte iagttagelse, at d'Hondts fordelingsmåde tenderer mod at favorisere de store partier. Det bemærkes i $\emptyset$ vrigt, at Venstres mandatandel ved brug af de to alternative fordelingsregler ikke bliver mindre end partiets andel af stemmerne. Det sker dog for Socialdemokratiet.

Kun under ekstreme omstændigheder kan man få fuld overensstemmelse mellem de to procentfordelinger, ikke mindst fordi mandaterne af indlysende grunde fordeles som heltal. Der er derfor udviklet forskellige indeks, der måler, hvor godt en given mandatfordeling afspejler den underliggende stemmefordeling. Hvis man bruger et forholdstalsvalgsystem, er et oplagt vurderingskriterium, i hvilken grad det benyttede mandatfordelingssystem er i stand til at sikre forholdsmæssighed i mandatfordelingen.

I fagkredse mener de fleste, at det mest hensigtsmæssige proportionalitetsindeks er det, som er udviklet af Michael Gallagher (1991: 40-41; Taagepera og Grofman, 2003; Lijphart, 1994: 60-61; Elklit, 2004: 42f.; for en anden opfattelse se Monroe, 1994 og Pennisi, 1998). Hovedprincippet bag Gallaghers indeks for disproportionalitet er, at større afvigelser mellem stemme- og mandatandele ved hjælp af kvadrering af afvigelserne bringes til at veje forholdsvis mere end mindre afvigelser, i øvrigt et princip, som allerede Elberling/Nybølle (1922: 333) brugte. 
Gallaghers indeks antager for Sindal i 2001 værdien 6,2, når man ser på den aktuelle mandatfordeling, men kun 2,9, når man ser på de to andre fordelinger (som jo i dette tilfælde er identiske). Værdien på indekset falder altså i dette tilfælde til under det halve, når man skifter fra det d'Hondtske mandatfordelingssystem til de to andre.

Sindal er brugt som eksempel, fordi der ikke var nogen forstyrrende valg- og listeforbund, der var kun fem lister, hvorved eksemplet bliver overskueligt, det største parti fik mere end halvdelen af stemmerne - og hertil mere end et helt mandat mere, end dets stemmeandel efter almindelig forholdsregning skulle berettige til. Venstres stemmetal berettigede efter almindelig forholdsmæssig fordeling til 8,996 af mandaterne, men partiet fik som anført ti mandater. Herved illustreres forskellen mellem de to fordelingsmåder klart.

De otte andre kommuner uden valg- og listeforbund i 2001 var Vallensbæk, Skævinge, Brørup, Fanø, Nykøbing-Rørvig, Ringe, Brædstrup og Gedved; valgresultaterne herfra er blevet gennemgået på samme måde som for Sindal. For de ni kommuner under ét er konklusionerne:

- Brug af største brøks metode ville i otte af kommunerne have medført en anden mandatfordeling og en markant mindre værdi på Gallaghers disproportionalitetsindeks end d'Hondts metode, idet enten det største eller det næststørste parti (eller dem begge) ville miste et mandat til et af de mindre partier. Brugen af største brøks metode ville i gennemsnit have reduceret værdien på Gallaghers indeks med knap 40 pct. I én kommune ville brugen af største brøks metode have givet samme mandatfordeling som i 2001.

- Brug af Sainte-Laguës metode ville i otte af kommunerne have givet samme mandatfordeling som største brøks metode, og værdien på Gallaghers indeks ville derfor blive reduceret i samme omfang. I én kommune flytter Sainte-Laguës metode imidlertid kun ét mandat, hvor største brøks metode ville have flyttet to, og her bliver værdien på Gallaghers indeks faktisk en anelse mindre end ved største brøks metode. Det overses ofte, at Sainte-Laguës metode ikke bare er helt på højde med største brøks metode med hensyn til at sikre en forholdsmæssigt optimal mandatfordeling, men også kan sikre dette mål bedre end største brøks metode.

- I to af de ni kommuner får det største parti ved brug af d'Hondts metode mere end et helt mandat mere, end det efter en forholdsmæssig fordeling kan siges at have krav på: Sindal er allerede omtalt; i Brørup ville en helt forholdsmæssig fordeling have givet Venstre 5,992 mandat, men partiet fik syv mandater.

Konklusionen på baggrund af de ni kommuner uden forstyrrende valg- og listeforbund er således klar: Største brøks metode ville i næsten alle tilfælde have ført til en mandatfordeling, der giver en væsentligt bedre forholdsmæssig afspejling af stemmefordelingen end d'Hondts metode. Det samme ville have været tilfældet, hvis Sainte-Laguës metode var blevet brugt. Denne konklusion svarer helt til, hvad man på baggrund af faglitteraturen skulle have forventet (Lijphart, 1986; Schuster et al., 2003; Gallagher 1991, 1992; Pukelsheim, 2000). 
Betydningen af valg-og listeforbund

Når man diskuterer over- og underrepræsentation i forbindelse med brugen af d'Hondts metode, nævnes muligheden for at indgå valgforbund ofte som et hensigtsmæssigt redskab til at reparere på de skader på proportionaliteten, som de store partiers indbyggede fordel medfører.

Her skal man imidlertid være opmærksom på, at anvendelsen af valgforbund har bredt sig på en måde, der kun kan betegnes som uhensigtsmæssig: Der er blevet flere og flere valgforbund - i 2001 var der valgforbund i 266 af de 275 kommuner - og valgforbund indgås ikke kun mellem mindre og nogenlunde nærtbeslægtede partier, som man må tro var den oprindelige tanke med denne mulighed for at modvirke de problemer, som d'Hondts metode skaber med hensyn til at opnå den forholdsmæssighed, som er en del af demokratiforståelsen her i landet.

$\mathrm{Nu}$ etableres valgforbund på kryds og tværs af det politiske spektrum (Lynge, 2002). Det er derfor blevet vanskeligere for både partier og vælgere at gennemskue såvel de politiske konsekvenser som virkningerne på mandatfordelingen, hvorved rimeligheden $\mathrm{i}$ et system med valgforbund under alle omstændigheder formindskes.

En yderligere komplikation er, at valgforbund ofte etableres mellem ét stort og et eller flere mindre/små partier. Det betyder, at valgforbundet bliver relativt stort, og det kan derfor tage en endnu større andel af de mandater, der er til rådighed. Valgforbund er altså ikke kun de små partiers beskyttelse mod den d'Hondtske fordelingsmådes urimeligheder. Hertil kommer, at d'Hondts metode også bruges ved fordelingen af de vundne mandater inden for valgforbundet. Det betyder, at skævvridningen til fordel for det store parti øges. Deltagelse i valgforbund cementerer altså yderligere det store partis overrepræsentation.

Virkningen af disse forhold er imidlertid vanskelig at studere systematisk, fordi der dels er mange kombinationsmuligheder, dels andre forhold, der spiller ind på slutresultatet. En gennemgang af valgforbundene i 2001 viser imidlertid, at de ingen mandatmæssig betydning havde i 136 af de 266 kommuner, mens de i 130 kommuner betød, at $i$ alt 138 mandater blev placeret anderledes, end de ellers ville være blevet placeret (Lynge, 2002: 95ff.). Partierne og lokallisterne både vandt og tabte mandater på denne konto. Nettoresultatet var værst for Socialdemokratiet, som på den konto mistede 52 mandater, mens SF, de konservative og lokallisterne havde en nettogevinst. Venstre og Dansk Folkeparti var begge nogenlunde i balance for hele landet under ét.

En anden mulighed er at se på de 84 kommuner, hvor ét parti har absolut flertal i kommunalbestyrelsen, og hvor der også var valgforbund. I 16 af disse kommuner var det store parti ikke med i noget valgforbund, og derfor burde virkningen af valgforbund kunne iagttages i netop disse kommuner.

Et eksempel er Gråsten, hvor hele tre valgforbund bidrog til, at Socialdemokratiet, som gik til valg alene, fik absolut flertal i kommunalbestyrelsen med 53,8 pct. af mandaterne for 48,4 pct. af stemmerne. Billedet er det samme i de $\emptyset$ vrige 15 kommuner, hvor det store parti (i et par tilfælde en lokalliste) gik til valg alene, mens de $\varnothing v r i g e$ partier og lister i forskellige kombinationer indgik i valgforbund (eller stillede op alene). Muligheden for at indgå valgforbund er altså ikke i sig 
selv nok til at imødegå store partiers overrepræsentation, jf. tabel 2. De 16 kommuner scorer også forholdsvis højt på Gallaghers disproportionalitetsindeks.

Tabel 2. Store partiers (listers) overrepræsentation i 16 kommuner, hvor de havde absolut flertal, ikke selv deltog i valgforbund og havde mindst et valgforbund imod sig. 2001

\begin{tabular}{lccccc}
\hline $\begin{array}{l}\text { Partiets } \\
\text { stemme- } \\
\text { andel }\end{array}$ & $\begin{array}{c}\text { Gennem- } \\
\text { snitlig } \\
\text { stemmeandel }\end{array}$ & $\begin{array}{c}\text { Gennem- } \\
\text { snitlig } \\
\text { mandatandel }\end{array}$ & $\begin{array}{c}\text { Gennemsnitlig } \\
\text { over- } \\
\text { reprasentation }\end{array}$ & $\begin{array}{c}\text { Gallaghers } \\
\text { indeks, } \\
\text { gennemsnit }\end{array}$ & $\begin{array}{c}\text { Antal } \\
\text { kommuner }\end{array}$ \\
\hline$-49,9$ & 48,7 & 53,1 & 4,4 & 5,2 & 5 \\
$50,0-59,9$ & 54,2 & 58,3 & 4,1 & 5,9 & 9 \\
$60,0-$ & 63,2 & 69,5 & 6,3 & 6,1 & 2 \\
\hline I alt & 53,7 & 58,1 & 4,4 & 5,7 & 16 \\
\hline
\end{tabular}

I de $\emptyset$ vrige 68 kommuner var det store parti (liste) med i et valgforbund, og i 22 af disse var det store parti (liste) så ublu at tage samtlige mandater, der gik til valgforbundet. Et eksempel er Brøndby, hvor et valgforbund bestånde af Socialdemokratiet, de radikale, $\mathrm{CD}$ og en lokalliste fik 13 af 19 mandater. Socialdemokratiet havde fået 58,6 pct. af stemmerne, men fik altså alle valgforbundets 13 mandater, dvs. 68,4 pct. af mandaterne i kommunalbestyrelsen (hvilket dog skal ses i forhold til, at valgforbundets partier tilsammen havde fået $66,1 \mathrm{pct}$. af stemmerne).

Ved en forholdsmæssig mandatfordeling ville Socialdemokratiet ud fra sit eget stemmetal kun have haft krav på 11,1 mandat, men fik altså 13. Forklaringen er, at de tre andre deltagere i valgforbundet havde for få stemmer til at få mandat ved fordelingen af de 13 mandater inden for valgforbundet. Ved brug af største brøks metode (uden valgforbund) ville de radikale og lokallisten begge have fået et af de tretten mandater. Hvis Sainte-Laguës metode var blevet brugt (på begge niveauer) havde Socialdemokratiet fået $12 \mathrm{og}$ lokallisten ét mandat, de radikale derimod ikke noget. Eksemplet svarer til, hvad der er set tidligere, for eksempel i Farum (Elklit, 1997a: 17).

Værdien på Gallaghers indeks for Brøndby 2001 er 8,1. Denne relativt høje værdi skyldes den dobbelte virkning af et stort valgforbund, som får en beskeden - og i det konkrete tilfælde helt uproblematisk - overrepræsentation, hvorefter storebror i valgforbundet med knap 89 pct. af stemmerne får alle mandaterne.

Billund har af de samme to grunde en høj værdi på indekset for disproportionalitet, men der ses også lavere værdier, fordi nogle af de partier, der går i valgforbund med et stort parti, ofte får relativt få stemmer. Begrundelsen for at indgå valgforbund med et stort parti må i disse tilfælde antages at være politisk og pragmatisk snarere end fors $\emptyset \mathrm{g}$ på at beskytte sig mod valgsystemets urimeligheder.

\section{Opsummering}

Dette afsnit har primært beskæftiget sig med, i hvilket omfang de tre metoder sikrer mandatfordelinger, der så proportionalt som muligt afspejler stemme- 
fordelingerne. De ni kommuner, hvor spørgsmålet bedst kan studeres, viste som forventet, at disproportionaliteten er størst, når d'Hondts metode anvendes.

Spørgsmålet om metodernes virkning på proportionalitetsgraden er vanskeligt at studere i de $\emptyset$ vrige kommuner, hvor forekomsten af valg- og listeforbund forstyrrer billedet og i hvert fald ikke i særlig stort omfang virker på den måde, der måtte forventes ud fra indenrigs- og sundhedsministerens svar. Det skyldes dels, at valgforbund, som store partier deltager i, nærmest virker modsat, dels at mønsteret for indgåelse af valgforbund er blevet mere varieret end tidligere, samtidig med, at indgåelsen af mere end et valgforbund normalt gør det nemmere for et stort parti at få løvens part af mandaterne.

Det er også blevet klart, at Sainte-Laguës mandatfordelingsmetode sikrer samme høje grad af proportionalitet som største brøks metode. Det svarer til resultaterne i andre nyere, empirisk baserede unders $\emptyset$ gelser (Pukelsheim, 2000; Benoit, 2000; Pennisi, 1998). Den bias til fordel for små partier, som brugen af største brøks og Sainte-Laguës metoder skulle medføre, er altså ikke specielt påfaldende.

\section{Billedet set fra valgernes side}

Én ting er, om partierne bliver ligeligt/retfærdigt repræsenteret. Noget andet er, hvorledes billedet ser ud, hvis man ser det fra vælgernes side: Har vælgerne samme mulighed for at blive repræsenteret (og i samme forholdsvise omfang), uanset hvilket parti de stemmer på? Denne tilgang til studiet af valgsystemer er mindst lige så vigtig som den tilgang, der tager udgangspunkt i partiernes situation (Elberling/ Nybølle, 1922: 333ff.; Pukelsheim, 2000: 241-249; Taagepera og Shugart, 1989: 67ff.; Pennisi, 1998: 6).

Udgangspunktet er altså, om ét partis vælgere bliver repræsenteret i samme omfang som andre partiers vælgere. I eksemplet ovenfor ses, at de 1.914 socialdemokratiske stemmer i Sindal (32,6 pct. af samtlige gyldige stemmer) rakte til seks mandater, dvs. 35,3 pct. De socialdemokratiske vælgere var altså heldige, idet der var et repræsentationsmæssigt overskud. Pukelsheim (2000: 243) taler om stemmernes "succesrate" (Erfolgswert), når han ser på forholdet mellem mandatandel og stemmeandel, som i idealsituationen er 1. For socialdemokraterne i Sindal var det 1,083. Taagepera og Shugart (1989: 68) bruger udtrykket advantage ratio (A) om samme fænomen (se også Taagepera og Laakso, 1980). Benoit (2000) fokuserer på grundlag af ungarske lokalvalg alene på A-værdien for det største parti, og Pennisi (1998: 6) minder om de sammenhænge, der er mellem udtryk, der fokuserer på stemme- og mandatandele, og udtryk, der parti for parti fokuserer på forholdet mellem mandat- og stemmetal (altså det, Elberling/Nybølle (1922: 333) kalder repræsentationsforskellen pr. vælger).

Taagepera og Shugart har ingen problemer med, at $\mathrm{A}$ antager værdien 0 (når et parti ikke har opnået mandater), mens Pukelsheim kun beskæftiger sig med værdierne for partier over spærregrænsen (dvs. fem pct. ved de valg i Bayern, han analyserer). Vælgere, der har stemt på partier, der ikke kom over spærregrænsen, ser han bort fra (og kalder dem lidt nedladende Umsonstwähler). I en analyse af valgsystemers virkning er dét en dårlig løsning, så her følges Taagepera og Shugart. Det ville også være misvisende at negligere partier, der på grund af de naturlige 
spærregrænser ved kommunalvalgene ikke får mandat. I modsætning til de formelle spærregrænser ved folketingsvalg (for eksempel de to pct.) gør der sig ved kommunalvalg nogle naturlige spærregrænser gældende, som betyder, at det for eksempel i en kommunalbestyrelse med 25 mandater er svært at få mandat med ret meget under fire pct. af stemmerne. Stemmefordelingen på partier og lister spiller dog også ind, hvorfor der faktisk er to af den slags grænser (Elklit, 2004: 38-41, tilsvarende 1997: 24-28). Den procentdel af stemmerne, der ville udelukke et parti fra mandat $i$ en kommune med en bestemt partistruktur, kunne i $\emptyset v$ rigt vise sig at være nok til at sikre partiet mandat et andet sted. Derfor ses der i det følgende på, hvilke muligheder alle partiernes og listernes vælgere har for at blive repræsenteret på lige fod med alle andre partiers og listers vælgere i samme kommune.

I tabel 3 ses for hver af de tre valgmåder A-værdieme for de fire partier og Borgerlisten i Sindal og deres vælgere. Desuden er anført en række andre mål: (1) afstanden mellem største og mindste A-værdi (jf. Pukelsheim, 2000), (2) summen af de kvadrerede afvigelser fra idealværdien 1,000, og (3) summen af kvadratafvigelserne multipliceret med partiernes vælgertal. Af hensyn til sammenligningen med Elberling/Nybølle (1922: 333-338) medtages endelig (4) et udtryk, der bygger på repræsentationsforskellen pr. vælger, som er forskellen mellem hver enkelt Sindal-vælgers andel af mandaterne $(17 / 5.875=0,00289)$ og hvert partis vælgeres faktiske mandatandel (for Venstre således $10 / 3.109=0,00322$ ).

Selv om der optræder større A-værdier i forbindelse med største brøks og SainteLaguës metode end i forbindelse med d'Hondts metode, er såvel variationsbredden og summen af kvadratafvigelserne fra idealværdien $(1,000)$ som begge de vægtede kvadratafvigelser væsentligt større ved d'Hondts end ved de to andre fordelingsmåder. Pennisi (1998) har tilsvarende resultater.

Sainte-Laguës metode sigter principielt mod at minimere forskellen mellem den enkelte vælgers repræsentation, og den, han burde have fået (Elberling/Nybølle, 1922: 338; Pennisi, 1998: 6; Pukelsheim, 2000: 247). Derfor er det interessant at se, hvad der sker, hvis man i forhold til Sainte-Laguë-fordelingen flytter et mandat fra det mest overrepræsenterede parti $(Q$, jf. A-værdien på 1,694), til det mest underrepræsenterede (A, med A-værdien 0,903). Resultatet ses yderst til højre i tabellen. Denne test giver dels en større forskel på A-værdierne, dels en kvadratafvigelsessum, der som forventet er større end ved brugen af Sainte-Laguës metode (og her også største brøks metode).

I relation til de to nederste afvigelsesmål (3. og 4.) ses igen, at flytningen af det mest "belastende" mandat ikke ændrer billedet: Som hos Elberling/Nybølle (1922: 332-338) kommer Sainte-Laguës metode (og i dette tilfælde også største brøks metode) nærmest, når udgangspunktet er repræsentationsforskellen pr. vælger. Det er altså lige efter bogen. Men også når man bruger kvadratafvigelsen fra 1,00linjen multipliceret med antallet af vælgere, der har stemt på hver af listerne (altså 3.), fås en større talværdi $(232,6)$ end ved Sainte-Laguës og største brøks metode. Så konklusionen er klar: Ved alle tre fordelingsmåder (samt testen) og på alle fire målestokke sikrer største brøk og den rene Sainte-Laguës metode - i hvert fald i dette tilfælde - den mest ligelige repræsentation af alle vælgerne uden hensyn til, hvilke partier eller lister de har stemt på. 
Tabel 3. A-værdier m.m. for partier/lister i Sindal 2001. Forskellige valgsystemer

\begin{tabular}{|c|c|c|c|c|}
\hline & d'Hondt & $\begin{array}{c}\text { Største } \\
\text { brøk }\end{array}$ & $\begin{array}{l}\text { Sainte- } \\
\text { Laguë }\end{array}$ & $\begin{array}{l}\text { Test af Sainte-Laguë: } \\
\text { Flytning af et mandat fra } \\
\text { det mest overrepræsen- } \\
\text { terede til det mest under- } \\
\text { repræsenterede parti }\end{array}$ \\
\hline A's vælgere & 1,083 & 0,903 & 0,903 & 1,083 \\
\hline O's vælgere & 0 & 1,225 & 1,225 & 1,225 \\
\hline Q's vælgere & 0 & 1,694 & 1,694 & 0 \\
\hline V's vælgere & 1,112 & 1,000 & 1,000 & 1,000 \\
\hline T's vælgere & 0,944 & 0,944 & 0,944 & 0,944 \\
\hline 1. Variationsbredde & 1,112 & 0,791 & 0,791 & 1,225 \\
\hline $\begin{array}{l}\text { 2. Summen af kvadrat- } \\
\text { afvigelserne }\end{array}$ & 2,023 & 0,545 & 0,545 & 1,061 \\
\hline $\begin{array}{l}\text { 3. Kvadratafvigelserne } \\
\text { multipliceret med } \\
\text { partiernes vælgertal }\end{array}$ & 539,3 & 131,7 & 131,7 & 232,6 \\
\hline $\begin{array}{l}\text { 4. Kvadratet på repræsen- } \\
\text { tationsforskellen pr. } \\
\text { vælger multipliceret } \\
\text { med partiernes vælgertal }\end{array}$ & 0,0045 & 0,0009 & 0,0009 & 0,0019 \\
\hline
\end{tabular}

Sammenligning af A-vaerdier for d'Hondts og største brøks metode i forskellige kommunegrupper

Advantage ratio-begrebet (som udtrykker repræsentationsover- eller underskuddet) er dels relativt letforståeligt, dels reelt ækvivalent med repræsentationsforskelsbegrebet; det vil derfor blive brugt til at belyse fordele og ulemper ved d'Hondts og største brøks mandatfordelingsmåder for vælgere, der stemmer på partier og lister af forskellige størrelse.

Figur 1 og 2 viser for samtlige partier i de ni kommuner, hvor der i 2001 hverken var valg- eller listeforbund, et plot af alle partiers A-værdier mod de pågældende partiers stemmeandel. I figur 1 ses situationen med d'Hondts valgmåde (altså den faktisk anvendte) og i figur 2, hvordan billedet ville have været, hvis største brøks metode var blevet anvendt.

Det billede, der tegner sig, er som forventet: I figur 1 ses, hvorledes næsten alle partier med mindre end godt ti pct. af stemmerne enten har en A-værdi på 0 (dvs. ingen mandater) eller er klart underrepræsenteret (dvs. ligger under 1,00-linjen). Partier med en vælgertilslutning på 10-20 pct. svinger omkring 1,00-linjen, hvorimod så godt som alle partier med en vælgertilslutning på 20 pct. og derover ligger over 1,00-linjen. Disse partiers vælgere har altså en repræsentation, der er forholdsmæssigt bedre, end deres stemmeandel berettiger til. Hertil skal føjes det ikke uvigtige forbehold, at der i de fleste tilfælde er tale om en overrepræsentation, 
Figur 1. d'Hondt: ni kommuner uden valg- og listeforbund

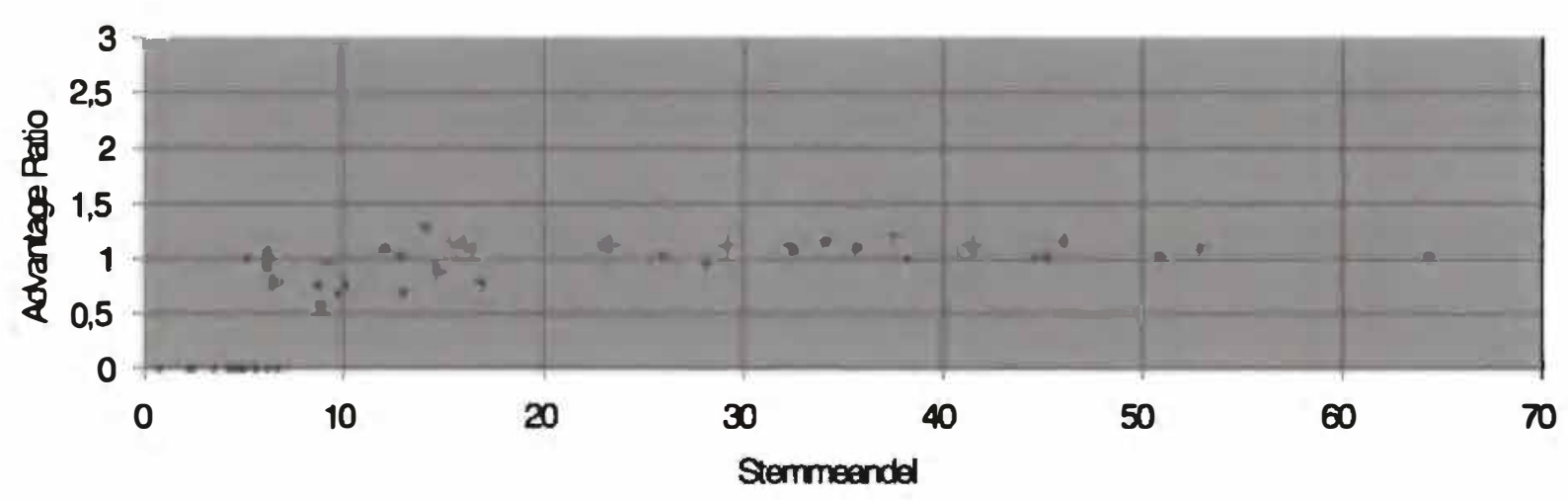

der udgør mindre, end hvad der svarer til et helt mandat; i sådanne tilfælde er det jo klart et mindre problem, end når overrepræsentationen udgør mere end et helt mandat (jf. de tidligere nævnte eksempler herpå). Det kan nu engang ikke undgås, at nogle partier får en over- eller underrepræsentation, der alt efter forholdene vil kunne beløbe sig fra ikke ret meget til næsten et helt mandat. Men også hvis overeller underrepræsentationen udgør mindre end et helt mandat, kan der være tale om et demokratisk problem; det er tilfældet, hvis der er en klar systematik i, hvilke partiers og listers vælgere det er, der over- eller underrepræsenteres.

Figur 2 viser for de samme partier og kommuner A-værdiernes fordeling, hvis mandateme var blevet fordelt efter største brøks metode. To ting fremstår klart: For det første ville partier med mere end 20 pct. af stemmerne ligge nærmere 1,00linjen, dvs. deres overrepræsentation mindskes, og for det andet ville partier i intervallet fra ca. to til ca. otte pct. få nemmere ved at blive repræsenteret; i et par tilfælde viser det sig som forholdsvis høje A-værdier. Realiteten bag disse høje Aværdier er, at nogle partier, som under d'Hondt ikke fik mandat, under største brøks metode får et enkelt af slagsen. Der er igen tale om naturlige konsekvenser af, at man ikke kan dele mandaterne i mindre brøkdele, og derfor vil der af og til forekomme høje A-værdier for partier med beskedne stemmeandele. Men sagen er altså i al sin enkelhed, at de pågældende partier og lister har fået ét mandat, hvor de under d'Hondt ikke ville have fået noget mandat.

Figur 2. Største brøks metode: ni kommuner uden valg- og listeforbund

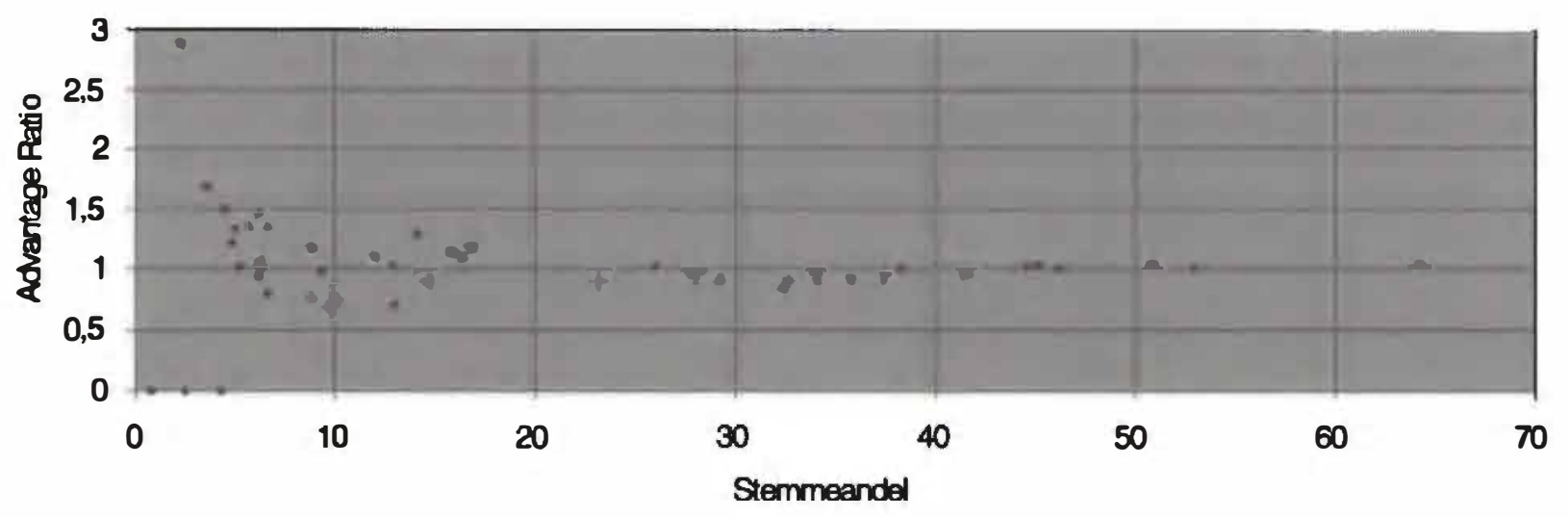


De ni kommuner uden valg- og listeforbund er alle relativt små, og man kan derfor spørge, om billedet i figur 1 og 2 er fortegnet i forhold til, hvad det ville være i større kommuner (som gennemgående har flere kommunalbestyrelsesmedlemmer). Figur 3 og 4 viser derfor billedet i de 50 kommuner, hvor der i 2001 blev afgivet flest stemmer.

Figur 3. d'Hondt: 50 kommuner med det største antal afgivne stemmer

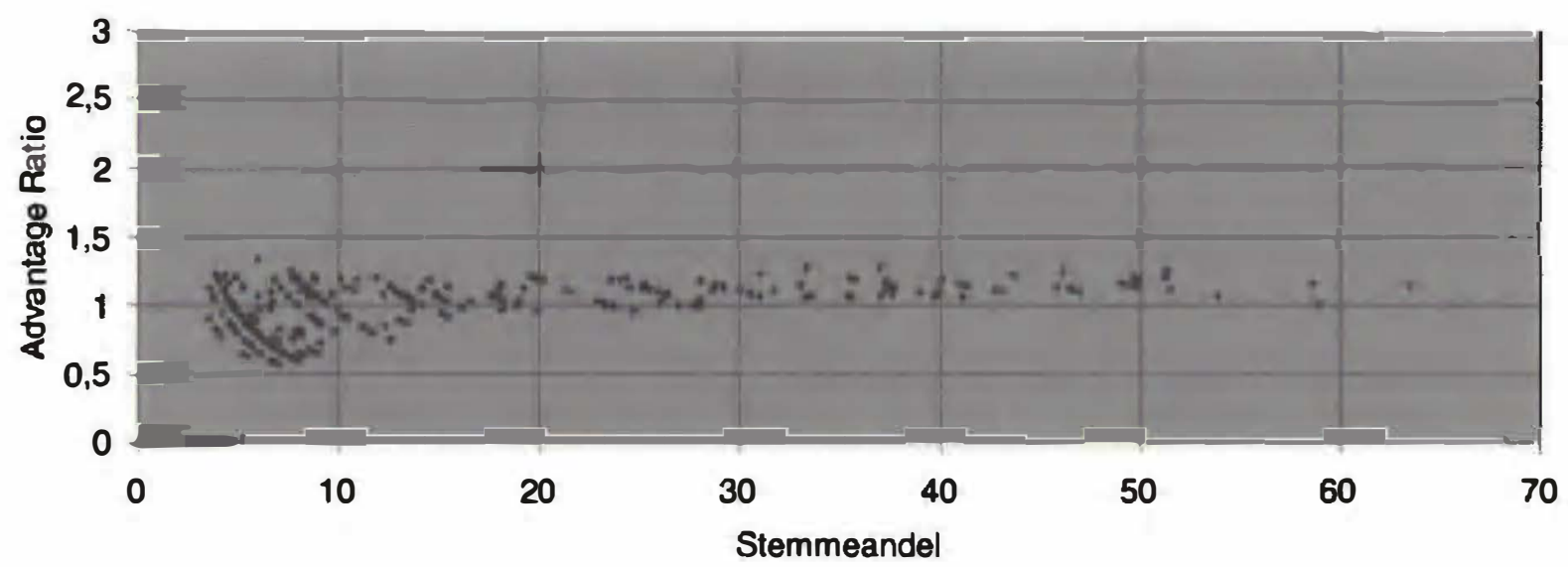

Fordi der er tale om store kommuner, minder de lokale partisystemer mere om det nationale partisystem, end tilfældet var i de ni små kommuner. Alligevel svarer billedet for både små, mellemstore og store partier til, hvad vi så i figur 1 og 2 , hvilket må tolkes i retning af, at hverken kommunestørrelsen eller forekomsten af valgforbund (som findes $i$ alle de 50 kommuner) er afgørende for graden af overog underrepræsentation under de to mandatfordelingssystemer.

Figur 4. Største brøks metode: 50 kommuner med det største antal afgivne stemmer

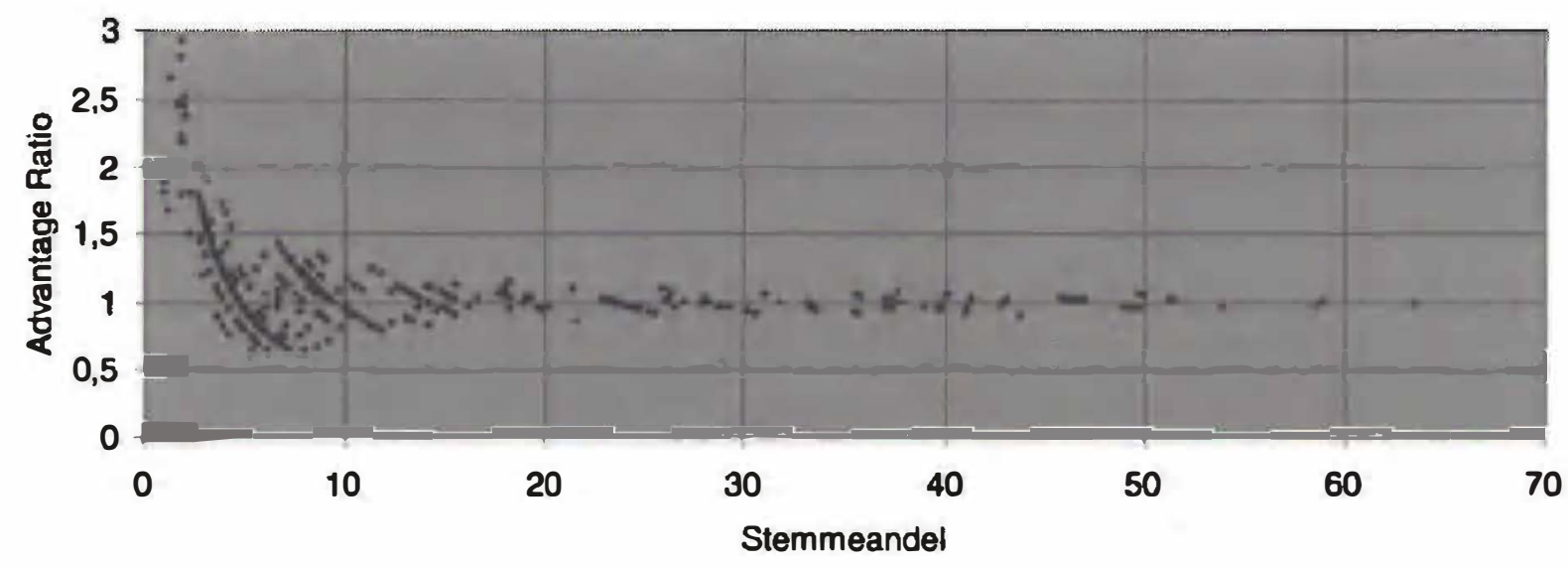

I figurer som disse ligger datapunkterne tæt; det er derfor svært at overskue, hvor mange partier og lister der faktisk ligger over eller under 1,00-linjen. I figur 3 ligger 49 partier og lister med under ti pct. af stemmerne på eller over 1,00-linjen, mens ikke mindre end 327 ligger under linjen. I figur 4 er de tilsvarende tal henholdsvis 128 og 248, dvs. der er også ved største brøks metode langt flere af de små partier under end over stregen. Men af de større partier og lister - med mindst 
ti pct. af stemmerne - ligger mere end 60 pct. over stregen, så det er vanskeligt at se, at brugen af største brøks metode skulle favorisere de små partier.

Efter at have set på situationen i små kommuner uden valg- og listeforbund og store kommuner med forskellige former for valgforbund, ses i de næste figurer på de 16 kommuner, hvor ét parti havde fået flertal af mandaterne, hvor det pågældende parti ikke havde været med i et valgforbund, og hvor det havde mindst ét valgforbund imod sig, jf. tabel 2. I figur 5 ses, hvorledes alle de store partier har Aværdier større end 1,00, mens partierne med stemmeandele på 10-20 pct. har ca. lige mange over og under 1,00. I området under ti pct. er der markant flest partier og lister under 1,00 (heraf ca. 50 med værdien 0). I figur 6 skifter billedet:

Figur 5. d'Hondt: 16 kommuner, hvor det største parti ikke var i valgforbund

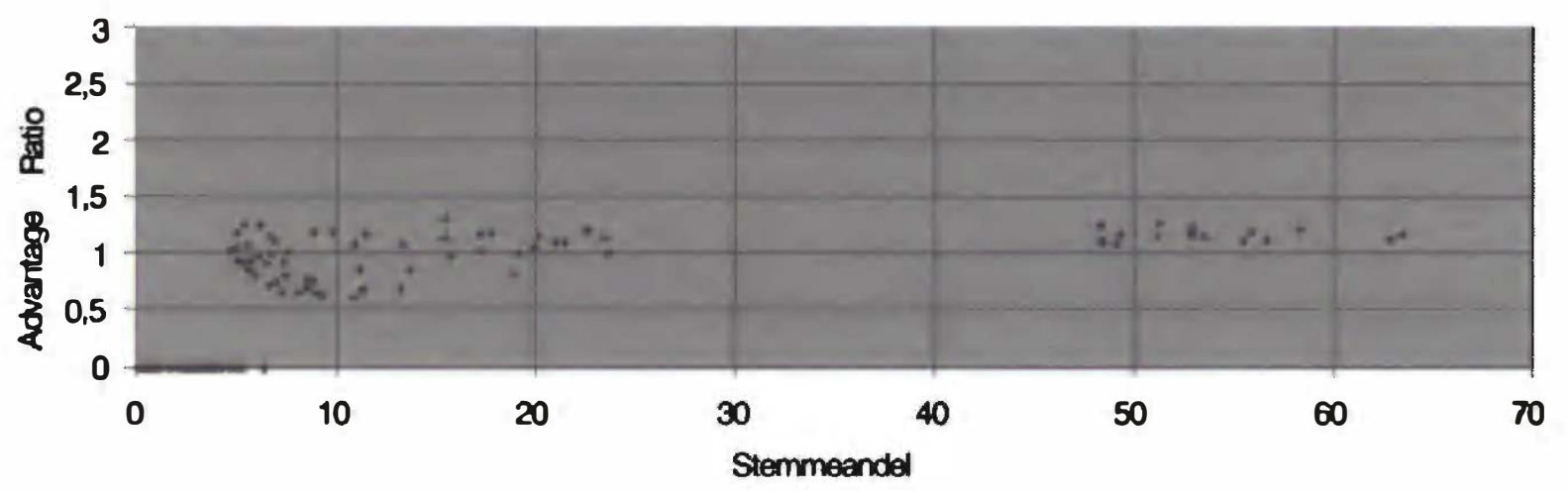

Dels får alle de store partier mandatandele, der mere tilfredsstillende afspejler deres stemmeandele, dels bliver fordelingen omkring 1,00-linjen for partier med mindre end ti pct. af vælgerne mere symmetrisk end før (der er dog 47 partier under og 36 over linjen). Igen ses de højeste A-værdier ved forholdsvis beskedne stemmeandele, selv om partierne og listerne kun har fået ét enkelt mandat. Der er således igen alene tale om forhold, der skyldes mandaternes udelelighed.

Figur 6. Største brøks metode: 16 kommuner, hvor det største parti ikke var i valgforbund

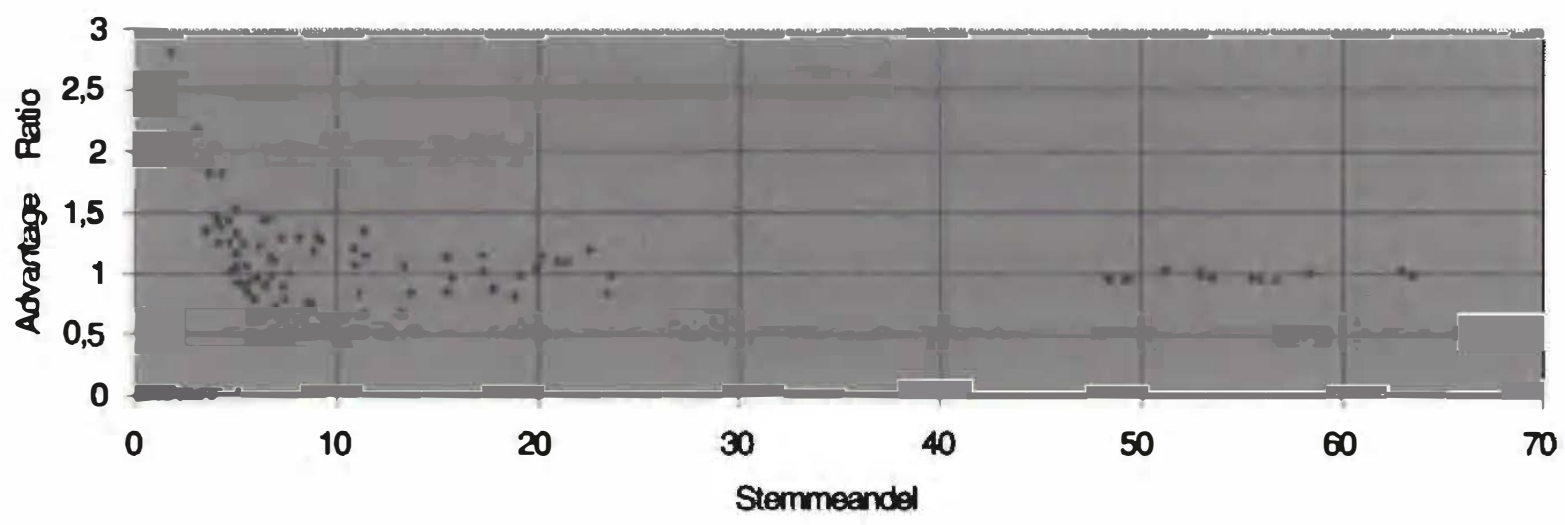

I figur 7 og 8 ses så på situationen i de 22 kommuner, hvor det største parti var med i et valgforbund, og hvor det var så ublu at snuppe alle valgforbundets mandater. Billedet er helt som før: De store partiers vælgere blev overrepræsenterede 
ved brugen af d'Hondts metode, mens resultatet ved brug af største brøks metode (figur 8) ville have været en langt mere tilfredsstillende repræsentation af disse partiers vælgere. Tilsvarende ses i figur 7 også en større spredning omkring 1,00linjen for partier med mindre end ti pct. af vælgerne bag sig. Men også her er der

Figur 7. d'Hondt: 22 kommuner, hvor det største parti var i valgforbund, og kun det parti fik mandat

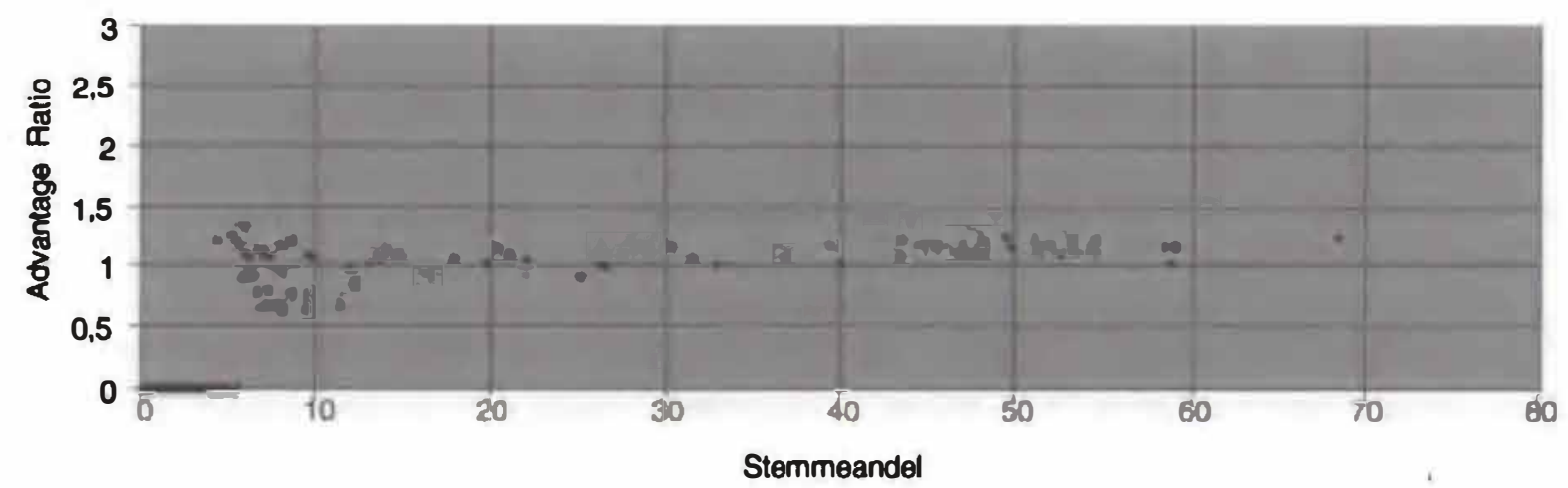

ved største brøks metode fortsat flere under- end overrepræsenterede blandt de små partiers vælgere. Indtil nu er der blevet set på fire grupper af kommuner, hvor der i den første ikke forekom valgforbund, mens der i de tre næste var forskellige kombinationer af små og store partier og deltagelse i valgforbund. Billedet af sammenhængen mellem mandatfordelingsmåde, partistyrke og A-værdier har imidlertid været meget lidt afhængigt af forskelle med hensyn til kommunestørrelse og forekomst af valgforbund, hvilket ses af den store ensartethed i de to sæt plots.

Figur 8. Største brøks metode: 22 kommuner, hvor det største parti var i valgforbund, og kun det parti fik mandat

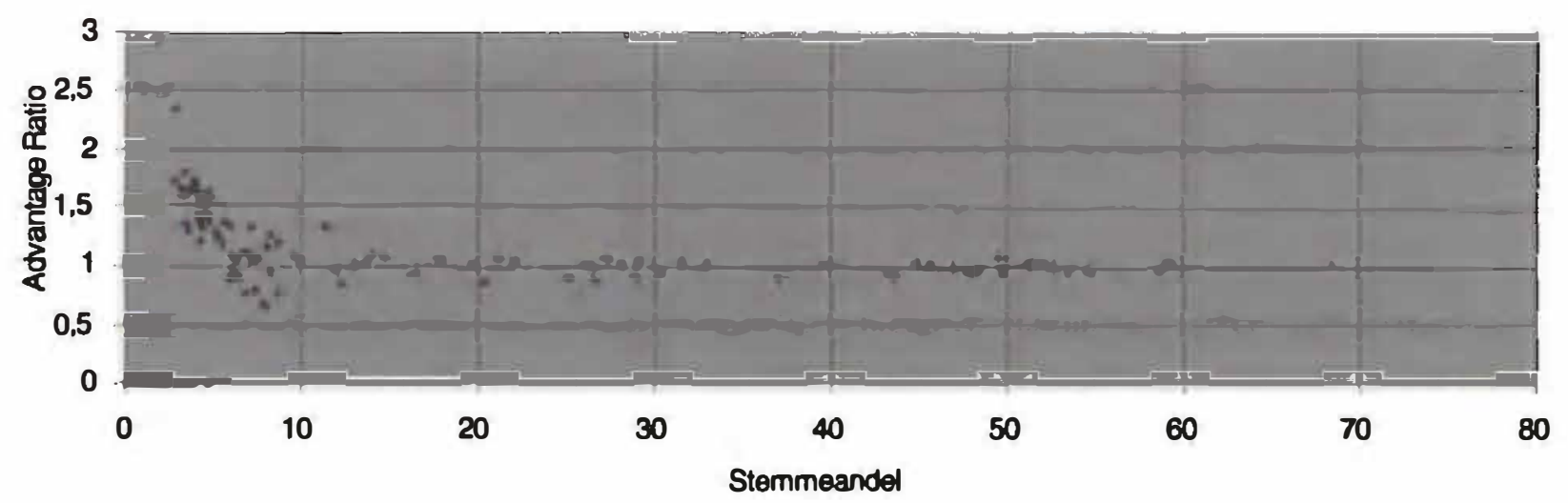

Figurerne 9 og 10 tegner det samlede billede for alle 275 kommuner. De godt 2.100 partier og lister, hvis repræsentationsstatus indgår, viser et meget klart billede, helt uafhængigt af forekomsten af valgforbund, og af, om de store partier er med eller ikke med i disse valgforbund: Under det d'Hondtske system overrepræsenteres partier med mere end godt tyve pct. af vælgerne systematisk, mens der er nogenlunde symmetri for partier med mellem ti og tyve pct.s vælgertilslutning. Derimod underrepræsenteres vælgere, der har stemt på partier og lister med mere 
beskeden vælgertilslutning, idet mindre end 15 pct. af disse har en A-værdi på 1,00 eller mere. Ophobningen af partier og lister med op til syv-otte pct. af stemmerne og ingen mandater $(A=0)$ er tydelig.

Figur 9. d'Hondt: 275 kommuner

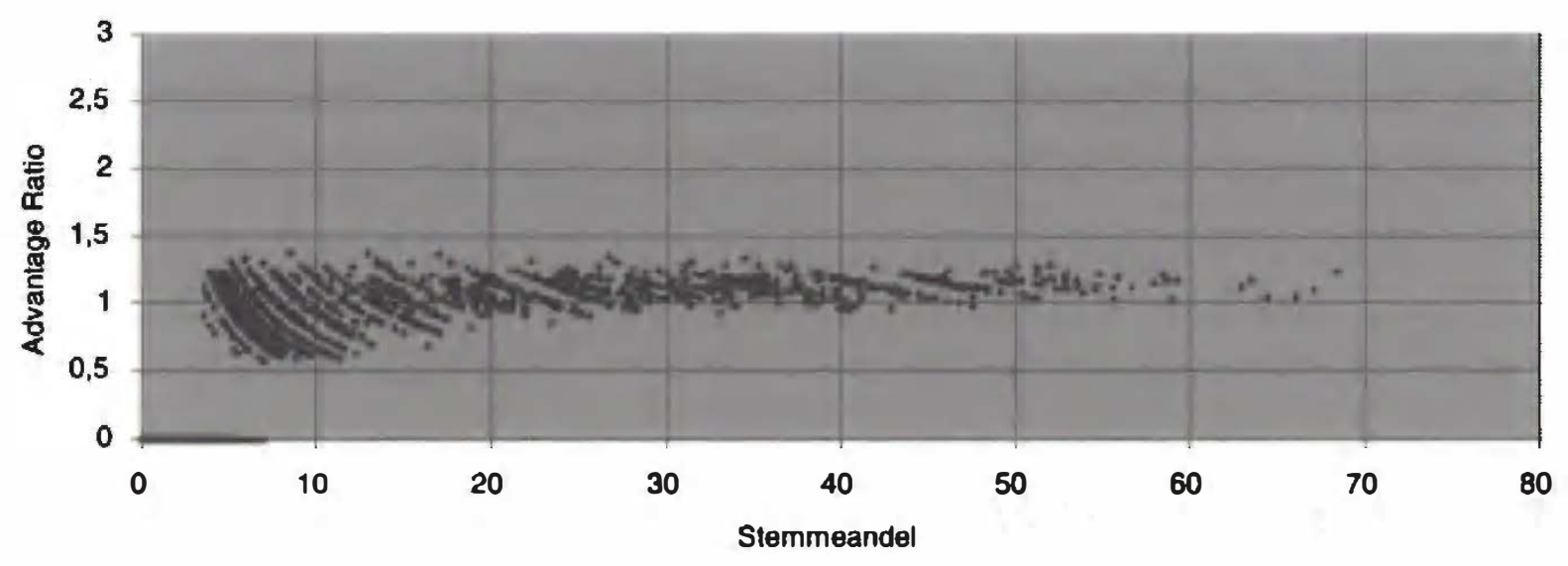

Tilsvarende ses i figur 10 billedet ved brug af største brøks metode, hvor der ved alle niveauer af partistyrke kommer en langt højere grad af symmetri ind i billedet end ved d'Hondts metode. Også her er der fortsat langt flere af de små partier under end over 1,00-linjen (mere end 60 pct.). Hvor der forekommer høje A-værdier, er der igen tale om overrepræsentation på mindre end et mandat.

Figur 10. Største brøks metode: 275 kommuner

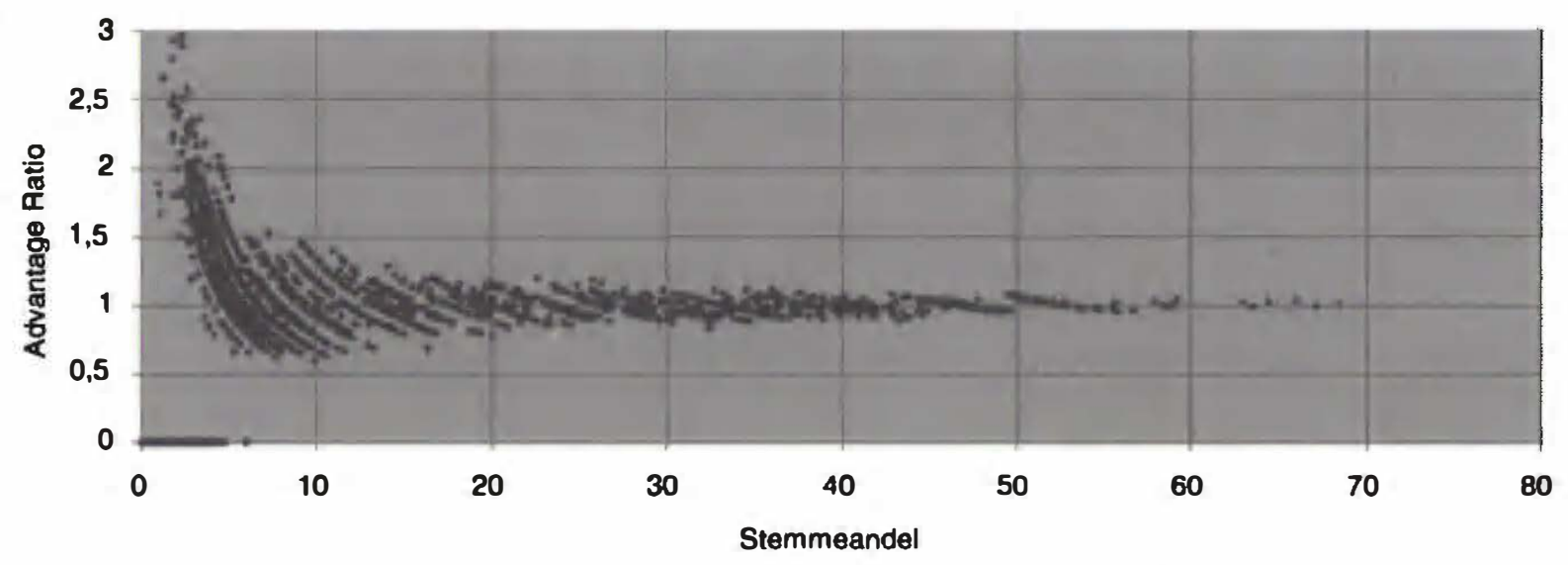

I figur 9 var mønsteret, at langt de fleste partier og lister med lave vælgerandele lå under 1,00-linjen, samtidig med at næsten alle partier med mellemstore og store vælgerandele lå over ideallinjen. I figur $10 \mathrm{er}$ billedet derimod, at de uundgåelige variationer omkring ideallinjen forekommer over et bredere og ud fra et inklusivitetsmæssigt synspunkt - dvs. et synspunkt, der lægger vægt på, at vælgerne bliver inkluderet $\mathrm{i}$ det politiske system også gennem en egentlig repræsentation - langt mere tilfredsstillende spektrum af vælgerstyrke hos partier og lister.

De ti figurer kunne naturligvis have været suppleret med et sæt, der viste fordelingen, hvis Sainte-Laguës metode var blevet brugt. De ville dog have ligget meget tæt på figurerne med brugen af største brøks metode. Derfor er de ikke 
medtaget. Til gengæld er for alle landets kommuner kvadratafvigelserne fra 1,00linjen blevet multipliceret med de relevante vælgertal for hver enkelt parti og liste (jf. tabel 3, næstnederste række). På grund af forskelle i vælgertal og mandattal er produkterne ikke sammenlignelige fra kommune til kommune. Tabel 4 viser i stedet de indbyrdes størrelsesrelationer.

Tabel 4. Størrelsesrelationerne mellem kvadratafvigelserne fra 1,00-linjen multipliceret med partiernes og listernes vælgertal for de tre mandatfordelingssystemer. 2001. $(\mathrm{N}=275)$

\begin{tabular}{lr}
\hline Indbyrdes størrelsesrelationer & Pct. \\
\hline D'Hondt > største brøk > Sainte-Laguë & 13 \\
D'Hondt > største brøk = Sainte-Laguë & 64 \\
D'Hondt = største br $\varnothing \mathbf{k}$ > Sainte-Laguë & 1 \\
D'Hondt = største brøk = Sainte-Laguë & 13 \\
Største brøk > d'Hondt > Sainte-Laguë & 4 \\
Største brøk > d'Hondt = Sainte-Laguë & 5 \\
\hline I alt & 100 \\
\hline
\end{tabular}

Tabel 4 understøtter meget klart det billede, som er fremgået ovenfor: Sainte-Laguë er i samtlige 275 tilfælde den mandatfordelingsmetode, der giver den mest ligelige repræsentation af alle partiers og listers vælgere - enten alene eller sammen med en af de to andre metoder (i 13 pct. af kommunerne dem begge). Den tilsvarende score for største brøks metode er 77 pct., mens den for d'Hondt er så lav som 18 pct. Dette svarer til, hvad man skulle forvente ud fra den nyeste litteratur, hvor Pennisis diskussion af disproportionalitetsindekser og fordelingsmetodernes robusthed er særlig interessant (Pennisi, 1998). Det følger dog ikke af litteraturen, at forholdet skulle være som i tabel 4, kun at rækkefølgen skulle blive den anførte. Det bør også understreges, at der fra kommune til kommune er forskel på, hvor tæt de beregnede værdier ligger på hinanden: Nogle steder er der ikke stor forskel; andre steder er forskellen betydelig.

\section{Hvad er så konklusionen?}

Artiklens udgangspunkt var indenrigs- og sundhedsministerens svar på et spørgsmål fra Folketinget, hvor konklusionen var, at der ikke fandtes argumenter, der kunne berettige, at man skiftede fra brugen af d'Hondts fordelingsmetode til største broks metode ved kommunalvalg eller valg til Europaparlamentet. Efter min opfattelse er der i hvert fald et par argumenter, som det trods alt kunne være værd at overveje, og som kunne føre til en anden konklusion end ministerens. Vurderingen af disse forskellige forhold vil utvivlsomt variere, men efter min opfattelse er der væsentlige argumenter, der peger i retning af, at største brøks metode er at foretrække for d'Hondts; under alle omstændigheder burde ministeren have nævnt, at der faktisk er sådanne argumenter. 
Nok så interessant er det imidlertid, at det også er fremgået ovenfor - helt i forlængelse af den nyeste faglitteratur - at den rene Sainte-Laguës fordelingsmåde har en række demokratiske kvaliteter med hensyn til såvel afbalanceret repræsentation af større og mindre partier som inklusivitet, der betyder, at den med fordel ville kunne indgå i diskussionerne om eventuelle ændringer i mandatfordelingsmåden til de kommunale (og tilsvarende) valg. Det er i den forbindelse ikke mindst vigtigt, at det er fremgået, at diskussionen om, hvilke fordelingsmåder der er til fordel for hvilke størrelseskategorier af partier, ofte har været ført på et lidt unuanceret grundlag. Det vil forhåbentligt ændre sig fremover.

Uanset om man ser på sagen fra partiernes eller vælgernes side (og i realiteten er der ikke grund til at sondre alt for skarpt, da der reelt er tale om to perspektiver på et og samme problem), kan resultaterne sammenfattes således:

- De forskellige partier og lister skal have en andel af mandaterne, der så pracist som muligt afspejler deres andel af voelgerne. Det må være en central målsætning, når valg afholdes som forholdstalsvalg. Der er ingen som helst tvivl om, at denne målsætning (som aldrig kan opfyldes fuldstændigt på grund af mandaternes udelelighed) for alle størrelseskategorier af partier og lister opfyldes bedre af største brøks og Sainte-Laguës metoder end af d'Hondts. Det er specielt interessant, at det nuværende system i nogle tilfælde sikrer store partier mere end et helt mandat mere, end de efter en strengt forholdsmæssig beregning kan siges at tilkomme.

- Valgerne - uanset om de stemmer på et parti, der ender med at blive stort eller lille - bør så vidt mulig reprasenteres ligeligt, dvs. med samme mandatandel. Det er mest rimeligt, og det bidrager også til det i et repræsentativt system ønskværdige, at flest muligt af vælgerne vil være direkte repræsenteret i det valgte organ og derfor også vil kunne føle sig inkluderet - og dermed medansvarlige - i det politiske liv. Den målsætning opfyldes også langt bedre af største brøks og Sainte-Laguës metoder end af d'Hondts. Og den lidt oversete Sainte-Laguës metode viser sig faktisk at opfylde denne centrale målsætning bedre end største brøks metode: Vælgerne ville blive mere ligeligt repræsenteret, hvis Sainte-Laguës metode blev indført som mandatfordelingsmetode.

Disse to punkter refererer til indenrigs- og sundhedsministerens synspunkter med hensyn til den matematiske retfærdighed i mandatfordelingen, jf. artiklens indledning. Med hensyn til de mere politiske hensigtsmæssighedsbetragtninger, som ministeren derefter tog op i sit svar, er synspunktet her vis-à-vis ministerens argumenter:

- Adgangen til at anmelde valgforbund udvander reelt de store partiers fordel under d'Hondt. Argumentet afspejler ikke virkeligheden i kommunerne, hvor dannelsen af valgforbund på tværs af størrelsesforhold og politisk ideologi sker af mange grunde, som ikke alle handler om at begrænse de store partiers fordel. Denne udvikling har bidraget til et for både vælgere og partier/lister uigennemskueligt billede, som det ville være hensigtsmæssigt at få forenklet. 
- Indførelse af største brøks metode vil kunne bidrage til flere partisplittelser, fordi der kan spekuleres $i$, at man kan voere heldig og få lidt ekstra ved brug af største brøks metode. Den form for argumentation bygger på teoretiske post hoc-argumenter, som typisk foregår efter et valg, hvor man kender stemmefordelingen (og historisk set hænger den utvivlsomt sammen med overvejelser hos de generationer af politikere, der 1866-1953 var involveret i de indirekte valg af landstingsmænd). Men det har ikke noget med dagens kommunale virkelighed at gøre - og hvis et parti af personlige og politiske grunde vil dele sig, hvad er der så galt i det? Det er vel ikke en målsætning for en demokratisk valglov at vanskeliggøre en naturlig og selvregulerende udvikling blandt partierne?

- I forbindelse med brug af største brøks metode kan der $i$ helt specielle tilfaelde konstateres nogle paradokser og uhensigtsmassigheder (for eksempel ved meget specielle stemmefordelinger eller opdeling af enhederne). Det er faktisk meget usandsynligt, at disse paradokser og uhensigtsmæssigheder forekommer, og der kan under alle omstændigheder - som det er sket andre steder lovgives for det tilfælde, at det alligevel skulle ske. Hvis for eksempel under største brøks metode et parti med et flertal af vælgerne en sjælden gang ikke skulle få sit velfortjente flertal af mandaterne, kan der naturligvis lovgives for at sikre det. Men risikoen for, at den situation skulle indtræde, er altså reelt nul.

På grund af diskussionens udgangspunkt har fokus været på forholdsmæssighed (matematisk retfærdighed) og ligelighed for partier og vælgere, og resultatet har været forholdsvis klart. Det er dog kun én side af sagen, idet spørgsmål som styringskapacitet, den optimale kommunalbestyrelsesstørrelse og andre spørgsmål, som Kommunalreformen aktualiserer, hverken kan eller bør negligeres, når man diskuterer mandatfordelingssystemer. Der er derfor mange temaer, der trænger sig på i diskussionen om det mest hensigtsmæssige kommunale valgsystem, ikke mindst $\mathrm{i}$ lyset af de kommende ændringer i den kommunale og regionale inddeling. Men at hævde, at der ikke er argumenter for at skifte mandatfordelingssystem, forekommer trods alt at være en lidt forhastet konklusion.

\section{Noter}

1. Tak til kolleger og andre - men især Flemming Christiansen og Søren Teglgaard Jakobsen - for konstruktive kommentarer og god hjælp undervejs.

\section{Litteratur}

Benoit, Kenneth (2000). "Which Electoral Formula is the Most Proportional? A New Look with New Evidence", Political Analysis, Vol. 8, No. 4, pp. 381-388.

Elberling, Vilhelm og Hans Cl. Nybølle (1922). "Om samtidigt Valg af flere Repræsentanter for samme Kreds", Bilag K til Betankning afgivet af den $i$ Henhold til Lov af 29. April 1921 nedsatte Valglovskommission, pp. 317-353, København: Schultz. 
Elklit, Jørgen (1997a). "Valgsystemet: Teori og praksis", pp. 17-33 i Jørgen Elklit og Roger Buch Jensen (red.), Kommunalvalg, Odense: Odense Universitetsforlag.

Elklit, Jørgen (1997b). "Kommunernes partisystemer", pp. 34-46 i Jørgen Elklit og Roger Buch Jensen (red.), Kommunalvalg, Odense: Odense Universitetsforlag.

Elklit, Jørgen (2004). Danske valgsystemer: Fordelingsmetoder, sparreregler, analyseredskaber, 8. udgave, Århus: Institut for Statskundskab, Aarhus Universitet.

Gallagher, Michael (1991). "Proportionality, Disproportionality and Electoral Systems", Electoral Studies, Vol. 10, No. 1, pp.33-51.

Gallagher, Michael (1992). “Comparing Proportionality Representation Electoral Systems: Quotas, Thresholds, Paradoxes and Majorities”, British Journal of Political Science, Vol. 22, pp. 469496.

Lijphart, Arend (1986). “Degrees of Proportionality of Proportional Representation Formulas”, pp. 170-179 in Bernard Grofman and Arend Lijphart (eds.), Electoral Laws and Their Political Consequences, New York: Agathon Press.

Lijphart, Arend (1994). Electoral Systems and Party Systems. A Study of Twenty-Seven Democracies 1945-1990, New York: Oxford University Press.

Lynge, Mads Toft (2002). Samarbejdsmønstre i de danske kommuner-et speciale med fokus på valgforbundsalliancer; deres udvikling og årsager samt de demokratiske konsekvenser, upubliceret specialeafhandling, Institut for Statskundskab, Aarhus Universitet.

Monroe, Burt L. (1994). "Disproportionality and Malapportionment: Measuring Electoral Inequity", Electoral Studies, Vol. 13, No. 2, pp. 132-149.

Pennisi, Aline (1998). "Disproportionality Indexes and Robustness of Proportional Allocation Methods", Electoral Studies, Vol. 17, No. 1, pp. 3-19.

Pukelsheim, Friedrich (2000). "Mandatszuteilungen bei Verhältniswahlen: Idealanspruche der Parteien", Zeitschrift für Politik, Jahrgang 47, Heft 3, pp. 239-273.

Reynolds, Andrew and Ben Reilly et al. (1997). The Intermational IDEA Handbook of Electoral System Design, Stockholm: International IDEA.

Schuster, Karsten, Friedrich Pukelsheim, Mathias Drton and Norman R. Draper (2003). "Seat biases of apportionment methods for proportional representation", Electoral Studies, Vol. 22, No. 4, pp. 651-676.

Taagepera, Rein and Bernard Grofman (2003). "Mapping the Indices of Seats-Votes Disproportionality and Inter-Election Volatility", Party Politics, Vol. 9, No. 6, pp. 659-677.

Taagepera, Rein and Markku Laakso (1980). "Proportionality Profiles of West European Electoral Systems", European Journal of Political Research, Vol. 8, pp. 423-446.

Taagepera, Rein and Matthew Soberg Shugart (1989). Seats and Votes. The Effects and Determinants of Electoral Systems, New Haven \& London: Yale University Press. 